\title{
O proročkome duhu Željka Mardešića
}

Ivan Supičić*

supicic.ivan@gmail.com
UDK: 316.2:2 Mardešić, Ž.

261.6

Izvorni znanstveni rad / Original scientific paper

Primljeno: 13 . listopada 2016.

Prihvaćeno: 11. studenog 2016.

Djelo Željka Mardešića snažno je obilježeno ujedno znanstvenošću i duhovnošću. Ali ono ima i nesumnjiv proročki karakter. Ne tek u smislu "predviđanja" budućih dogadaja nego i u tome što njegovi uvidi sežu u dubine nekih realnosti koje drugi autori u Hrvatskoj nisu uočili niti ih ikako iskazali. Otuda $i$ važnost tog proročkog obilježja. A ti uvidi se tiču ne samo nekih užih aspekata nego $i$ daleko širih realnosti u koje je uronjen napose današnji čovjek, ali $i$ čovjek svih vremena. Suvremeni je čovjek osobito izložen samozavaravanju, rascjepima $u$ sebi, prividnostima i opsjenama. On često laže sebi i drugima, prikazuje se autentičnim, a zapravo je otuđen, želi samo izgledati, a ne doista biti. Mardešićeve se proročke projekcije nadovezuju na njegove znanstvene konstatacije $i$ cjelokupan duh njegova djela, pa tako napose $i$ na one o budućnosti Crkve $i$ kršćanstva. Otuda i njegovo isticanje prijeke potrebe da Crkva, kako ne bi izdala svoj izvorni smisao, bude Crkvom siromaha i zapostavljenih, Crkvom dobrote $i$ milosrdne ljudskosti, Crkvom nade i radosti, Crkvom mirotvorstva, pomirenja $i$ praštanja te Crkvom iskrena dijaloga sa suvremenim svijetom. Otuda takoder Mardešićevo zauzimanje za posve personalističko kršćanstvo, izvan kolektivističkih $i$ ideologijskih vizija, zauzetost za prestanak povezivanja kršćanstva s politikom, koje je dovelo u prošlosti do poraznih deformacija, te nastojanje na povjerenju u slobodu i slobodnog čovjeka. Svijet se može nastojati promijeniti samo ako se najprije pokuša promijeniti samoga sebe, zaključuje Mardešić. Kršćanstvo budućnosti mora ponovno pronaći svoje iskonsko »ljudsko lice«, koje nije drugo doli samo božansko-ljudsko lice Isusa Krista.

Ključne riječi: Željko Mardešić, proročki duh, izopačenja svijesti, kršćanstvo s ljudskim licem, budućnost Crkve i kršćanstva.

\footnotetext{
* Akademik Ivan Supičić, HAZU, Trg Nikole Šubića Zrinskog 11, HR-10000 Zagreb.
} 
Nakon smrti Željka Mardešića o njegovu se znanstvenom djelu i o raznim aspektima toga djela prilično pisalo. Održani su o njemu i neki znanstveni skupovi te objavljeni vrijedni analitički tekstovi znatnog broja autora. Znanstveni se radovi dakako bave otkrivanjem, utvrđivanjem i interpretacijom činjenica, pa je tako bilo i u Mardešićevu znanstvenom opusu. Taj se opus, međutim, nije zaustavljao na tom aspektu. U misli, djelu i djelovanju Željka Mardešića snažno je prisutan i drugi, duhovni i proročki aspekt, koji nije ostajao na pukoj konstataciji i interpretaciji nepobitno utvrđenih znanstvenih činjenica iz prošlosti i sadašnjosti nego je sadržavao i »projekciju« koja ih nadilazi i kojom je otvarao pogled na razna, a osobito na poželjna usmjerenja života, zbivanja i djelovanja u budućnosti.

No, Mardešićev proročki duh stoji još u nečemu, daleko dubljemu, a to su uvidi u bît svega (Boga, čovjeka i svijeta), koja se tiče svih vremena i sredina. Mardešić je svim srcem bio tražitelj baš te bîti i njezinih vrijednosti u svemu: čovjeku, društvu, politici, religiji, kršćanstvu i Crkvi, i to s posebnim obzirom na sadašnji povijesni trenutak. Otuda i njegov proročki »vapaj« i traženje tih vrijednosti i njihove istine, ulaženje u srž cjelokupne nam umu i duhu dostupne stvarnosti kako im se ona u naše vrijeme predstavlja. Raspravljati o ovom ili onom aspektu Mardešićevih pogleda i uvida koji se tiču spoznaji pristupačnijeg sloja života i svijeta, njihove pojavnosti i zbivanja te njihovih pojedinih aspekata iz prošlosti i sadašnjosti, a ne vidjeti tu dublju, utemeljiteljsku, proročku pozadinu njegova duha i misli, zanemariti je ili izostaviti - značilo bi zaustaviti se samo na dijelu puta i propustiti cjelinu i ono što je presudno konstituira. Bio bi to ogroman promašaj.

Proročka je misao pretežno upravljena na budućnost, ali se nipošto ne ograničava na predviđanje ili nagovještavanje budućih događaja nego sadrži i poruke koje, izvirući iz sadašnjosti i iskustava iz prošlosti, izriču bitno i temeljno na način na koji ih »neproročka« misao ne dotiče. Proročki karakter iskaza i poruka stoji uostalom i u tome da ih netko kaže na dublji način na koji ih nitko drugi ne iskazuje, ne vidi, možda čak ni ne naslućuje, da budu na neki način jedinstveni. »Proricati« ne znači samo gledati i vidjeti dalje nego i dublje. Mardešićeva proročka vizija sadašnjosti i budućnosti, kao i njegova projekcija mogućih budućih usmjerenja i događanja te potrebe da se realiziraju u što čišćemu evanđeoskom duhu, oslobođeni od svih natruha i negativnih povijesnih devijacija, deformacija i neistina, kojima su bili često opterećeni u prošlosti, a u nečemu su još i u sadašnjosti, vrlo su značajne i jake. Dotle da Mardešića snažno i bitno karakteriziraju čineći od njega ne samo znanstvenika, koji tek konstatira i interpretira činjenice i zbivanja iz prošlosti i sadašnjosti, nego i duhovnog učitelja koji snažno priziva veliki, dapače sveopći duhovni i misaoni napor u službi konkretnoga života ljudi, društva i Crkve na svim važnim poljima, od religijskih do socijalnih i političkih te nadasve općeljudskih.

Upravo je u tome veličina i vrhunska vrijednost njegove misli i njegova duha, nastojanja i djelovanja. Isticati sve ostalo i raspravljati o njemu, a zanemariti 
ovo bilo bi jednako izdaji autentičnosti, cjelovitosti i vrijednosti njegova životnog djela i duha. Njihova važnost stoji u upravo dramatičnome pozivu na visoku viziju i misiju kršćana i Crkve danas, kakav se još nije čuo ni od koga drugog u nas. Uostalom, Mardešićev se glas nadovezuje na mnoge druge, slične njegovu, izvan Hrvatske, u Europi i svijetu, što samo potvrđuje njegovu važnost i utemeljenost. Duhovno sazrijevanje istih ili sličnih novih težnji na raznim mjestima zemaljske kugle kod ljudi različitih usmjerenosti misli i duha uvijek je znak vremena i njihove aktualnosti i vrijednosti te potrebe izlaska iz užih uhodanih obrazaca. A proročki glas uključuje ne samo viziju budućnosti nego i poziv da se ona učini sadržajnijom i ispunjenijom duhom, da se u njoj promijeni i poboljša mnogo toga što ne zadovoljava u sadašnjosti. To obilježje je bilo vlastito i vapaju biblijskih proroka koji je, međutim, često ostajao uzaludan. Takvim bi se, kao što je to bilo dosad, a dobrim je dijelom i danas, mogao nažalost pokazati i Mardešićev glas u sadašnjem i dolazećem vremenu u njegovoj domovini Hrvatskoj.

\section{O svjetlu i sjenama svijesti}

U velikoj povijesnoj freski modernog i postmodernog svijeta, koju na razne načine i na više mjesta u svojim radovima oslikava Mardešić, nije on mogao mimoići među ostalima ni filozofe i znanstvenike kakvi su bili Nietzsche, Marx i Freud, koji su taj svijet tako snažno obilježili. Mardešić je u njih opravdano razlikovao ne samo neke njihove neutemeljene filozofske zasade, pa i zablude, od pojedinih kapitalnih znanstvenih otkrića, nego i ono što bi se moglo nazvati njihovim duhom za razliku od samo znanstveničkog doprinosa. Svaki od trojice tih autora pridonio je na svoj način i na svom posebnom području istraživanja otkrivanju nekih istina i laži o čovjeku i društvu, i to ne samo njihova vremena, nego mnogo šire. No, koliko se god Mardešićeve konstatacije tiču više-manje svih vremenā, neke se napose i osobito tiču baš modernog i postmodernog svijeta. Tako i kad kaže:

»Mi smo uvijek i neizostavno izloženi obmanama, lukavstvima, rascjepima u sebi, prividnostima i opsjenama... Zato valja izaći iz tih zamki i paučina svijesti i početi se navikavati na to da izvanjska uvjerljivost malo vrijedi ako nije potvrđena unutrašnjim duhovnim pristankom.

Čovjek može i sebi lagati. To umijeće stalnog lučenja i razlučivanja pokazanog $\mathrm{i}$ skrivenog, učinjenog i glumljenog, istinitog i lažnog stavlja moderne ljude pred golem napor propitkivanja vlastite iskrenosti i čišćenja vlastite svijesti...

Dolazi takav naraštaj koji riječima malo ili ništa ne vjeruje, posebice ne propovjednicima vjere i morala. Od njih se traže djela i svjedočanstva, iskrenost i skromnost. $\ll^{1}$

${ }_{1}^{1}$ Ž. MARDEŠIĆ, Politički dualizam i koncilsko kršćanstvo, Nova prisutnost, 1 (2003) 1, 5-27, 6. 
Izloženost obmanama i rascjepima svih vrsta konstanta je ljudskog života, društva i povijesti. Ona proizlazi iz ljudske psihe i ega, iz podsvjesne sfere čovjeka. Svako (samo)zavaravanje porobljava čovjeka. A težnja za slobodom od svakog robovanja nesvjesnom i rascjepima u sebi na osobnom i društvenom planu dio je duhovne bitke koju se ne može zaobići. Sve ljudske zajednice, i civilne i religijske, ne samo pojedinci, mogu spontano ili svjesno upasti u razne devijacije i deformacije vezane uz pomanjkanje samokritičnosti i poštenog pogleda na sebe. Postoji ne samo individualni nego i kolektivni patološki ego kao zapreka jasnom i istinitom viđenju sebe i drugih. Ljudska nesvijest i neznanje, sa svim posljedicama koje uključuju korijen su mnogih zala. A te su posljedice među ostalim: predrasude, zatvorenost, zatucanost, isključivost, netrpeljivost, dogmatizam, nepovjerenje i strah - pojave na koje je Mardešić uporno upozoravao.

Izloženost prividnostima i opsjenama vrlo je bliska ovoj netom navedenoj. Podsvjesna je to, ali često i svjesna »igra« istinskih lica i lažnih maski, licemjernog pokazivanja svijetu onog što tobože jesmo, a stvarno nismo. Mardešić je uostalom napisao cijelu jednu knjigu u kojoj je pokazao kako taj dvoboj lica i maski može itekako zahvatiti i religijsku sferu. ${ }^{2}$ A nošenje maski je jedna od laži i deformacija, sveprisutna u ljudskome svijetu, gdje čovjek sebe predstavlja boljim i drukčijim od onoga što i kakav stvarno jest. Otuda gotovo univerzalno pretvaranje i glumljenje kao instinktivno i u podsvijesti ukorijenjeno ponašanje, koje se može zapaziti već u djece, kad žele sebe prikazati boljima ili »dobrima« ili se nekako opravdati u situacijama opterećenima krivnjom, što poprima dakako čak monstruozne razmjere na društvenom i napose na političkom planu u svijetu odraslih. Među političarima, ali nažalost i kod kleričkoga personala, od iskona do danas gotovo posve odsutna samokritičnost i postavljanje sebe iznad drugih, kako bi se postigao privid moralnosti i ispravnosti, široko su rasprostranjena pojava, čak konstanta, koja govori o elementarnom psihološkom mehanizmu, o zakonitosti ljudske psihe, a nipošto ne o nekoj intelektualnoj ili duhovnoj zrelosti, a pogotovo ne superiornosti. Takve deformacije samo su dio onog robovanja kojim ljudska društva, a napose neki njihovi dijelovi, odnosno slojevi, od iskona do danas pritišću druge ljudske skupine, osobne savjesti i slobodu čovjeka pojedinca. Koliko god društvo podržavalo u nekim aspektima čovjeka, toliko ga oduvijek i okrutno ograničava, gazi i porobljava. Čovjek je njegova žrtva. A prividnosti i opsjene najčešće su sredstvo u službi tog ropstva.

Izlaskom iz zamki i paučina svijesti Mardešić naziva izlazak iz svakog robovanja koje se služi lažima i prijevarama, zamagljivanjem i izbjegavanjem istine. A iz takvih se zamki može izaći jedino duhovnim naporom i usponom, s one strane posve psihološkog i instinktivnog, nesvjesnog i sjenovitog ili tamnog. No, premda se to može nazvati i tako kako to čini Mardešić, moglo bi

${ }^{2}$ Usp. Ž. MARDEŠIĆ (Jakov JUKIĆ), Lica i maske svetoga. Ogledi iz društvene religiologije, Zagreb, Kršćanska sadašnjost, 1997. 
se primijetiti da je tu više riječ o nesvijesti nego o svijesti: potreban je izlazak iz stanja nesvijesti k što punijoj svijesti, iz tame laži k svjetlu istine. Zapletenosti vlastitim prikrivanjima, licemjernim pretvaranjima, himbom i prijetvornostima, individualnim i kolektivnim, gdje se laži prikazuju istinama, hod je putem manjeg otpora, nadomještanje živoga Duha mrtvim slovom, zamjena življenja u ljubavi, povjerenju, poštovanju i odanosti prema čovjeku skučenim pravilima, uskogrudnim propisima i ubitačnim »zakonima«, koji su ljudska izmišljotina (a ne Božja riječ) i u religijskim i u civilnim zajednicama.

To što dolaze novi naraštaji koji riječima malo ili ništa ne vjeruju, a osobito ne navjestiteljima vjere i morala, nije samo znakovita pojava nego i pravi znak vremena.

Ti propovjednici vjere i morala su ljudima predugo lagali i previše ih varali ne dajući im često, povrh toga, uvjerljiv i dovoljan primjer vlastitim životom tako da se njihove riječi uzmognu uzeti ozbiljno. Oni pripadnici kleričkoga personala koji su, dobro ugojeni, propovijedali vrline siromaštva gladnima i bijednima, te kad su unutar sigurnosti i usidrenosti unutar zidina svojih dvorova i dvoraca, kraj obilnih trpeza, govorili - siti i bogati - zanemarenima i obespravljenima o blagodatima lišenosti od bogatstava ovoga svijeta, postajali su licemjerni protuprimjer i glavni uzrok odbacivanja onoga što su govorili, pa čak i samih vjerskih zasada: time su sami sebe svrstali među one farizeje koji, prema Kristovoj riječi, »govore, a ne čine«. Teško je nešto drugo reći i o lažnim čuvarima istina vjere i morala koji svisoka dijele lekcije drugima, sudeći i osuđujući druge kao da su sami uzorni i neprikosnoveni. Mardešić je jasno vidio da prazne riječi više ne djeluju, da se danas traže djela, iskrenost i vjerodostojna svjedočanstva kao istinski plodovi Duha.

Opisujući tako današnje stanje Mardešić zapravo postavlja golemu proročku zadaću pred kršćane sadašnjega vremena koja traži velik, monumentalan duhovni napor da bi je se počelo djelotvorno i vjerodostojno rješavati. To je proročki poziv za budućnost.

\section{Kršćanstvo s ljudskim licem}

U vrlo kratkom tekstu ovoga naslova Željko Mardešić je sažeo bît onoga što je pod tim naslovom htio reći. ${ }^{3}$ Riječ je o jednoj od temeljnih duhovnih zadaća suvremenih kršćana, a ta je da se kršćanstvu vrati njegovo pravo, izvorno i istinsko lice. U prošlosti su mnogi kršćani i pseudokršćani pokazali svijetu toliko naopako, lažno i iskrivljeno lice kršćanstva, kakvo s njim nije imalo ništa zajedničko, tako da je to lažno lice mnoge ljude od kršćanstva udaljilo i odvratilo jer su umjesto njegove autentične slike dobili njegovu karikaturu, njegovu

${ }^{3}$ Usp. Ž. MARDEŠIĆ, Kršćanstvo s ljudskim licem, Crkva u svijetu, 33 (1998) 2, 99-100. 
iskrivljenu i krivotvorenu sliku. Odgovornost za takvo lažno svjedočenje i protuprimjer je golema jer su njegovi nositelji svojim životima i ponašanjem često »stvarali« ateiste i antiteiste, ljude koji su se duboko razočarali poistovjećujući zli primjer takvih ljudi sa samim kršćanstvom, što je dakako psihološki razumljivo koliko god bilo i neopravdano jer je autentičnom kršćanstvu taj primjer bio potpuna suprotnost. Evanđelje, kršćanstvo i kršćanski svijet treba jasno razlikovati, što mnogi ne čine ili ne znaju učiniti. A tako i Crkvu od njezina kleričkog personala. Ne reducirajući uzroke ateizma samo na to, može se ipak smatrati da su često prvi uzrok ateizma bili kršćani. No, ostaje činjenica da su mnogi kršćani svjedočili svoju vjeru autentično i vjerodostojno, što ju je iznad svega činilo privlačnom, pa i neodoljivom. Kao što je pisao Mardešić:

»Danas je više nego očito da se religije ne mogu vrednovati samo po onome što uče nego prije svega po onome kako žive to učenje. Vjernost izvornoj poruci prvo je i nepreskočivo mjerilo svake autentičnosti... A upravo pregled zbivanja u svijetu pokazuje da u naše doba religije zabrinjavajuće sudjeluju u ratovima, mržnji, podjelama i nasilju... Povijest obilno pokazuje da su kršćani kroz svoju dugu povijest prolazili slična stanja i istovjetna ponašanja... Danas religije mogu privući pozornost jedino vjerodostojnošću svojeg življenja i dobrotom svojih pothvata. $\aleph^{4}$

Propisi, pravila, formalizam, legalizam, juridizam, fundamentalizam i ideološko doktrinarstvo pravi su neprijatelji kršćanstva. A u povijesti Crkve, i osobito njezina kleričkog personala, bilo je i previše devijacija te vrste. One su izrazit primjer suprotnosti onome što je Krist snažno istaknuo i što čini jedan od temeljnih stupova njegove poruke koja vrijedi za sva vremena i sredine, kroz svu povijest. U središtu i na vrhu Božjega svijeta je čovjek. I upravo zato je čovjekova sloboda bitna. Krist nije nikoga ni u čemu prisiljavao nego je samo pozivao i poticao. Krista se može ozbiljno istinski prihvatiti jedino bez pritisaka i prisile, slobodnim obraćenjem, koje je proces i ono jedino vrijedno. Prianjanje uz Krista i kršćanstvo nije pitanje pripadništva i sljedbeništva unutar ljudskih, pa ni religijskih skupina i zajednica, nego pitanje duboke unutarnje, duhovne preobraze, metanoje. Mentalno ili intelektualno (i emotivno ili afektivno) pristajanje uz Evanđelje, kao ni jeftina vjera bez dubinskog uvjerenja, ne vrijede mnogo ako se do njih dolazi na neki izvanjski ili čak prividan način, zbog odgoja, utjecaja obitelji, škole, okoline, običaja, nacije, politike ili kulture. To sve ne mora dovoditi do istinskog i slobodnog življenja vjere ni do slobodnog i dubljeg unutarnjeg duhovnog pristanka čovjekova o kojem govori Mardešić. Ne samo da ne mora dovoditi, nego često ni ne dovodi.

»Za opredjeljenje u korist čovjekova dobra i služenja njemu - što možemo nazvati integralnim humanizmom - kršćanstvo ima dodatno opravdanje i poticaj u Evanđelju i u učenju Drugoga vatikanskog koncila... Izvan toga je sve ideologija i struktura... Odgovor na te izdaje i zaokrete valja tražiti u molitvi, povjerenju,

${ }^{4}$ Isto, 99. 
dobroti, čovjekoljublju, optimizmu, nadi i vjeri. Vjeri u Boga i čovjeka. Jedini istinski neprijatelj kršćaninu je on sam, 'stari čovjek' u njemu. Drugo su sve projekcije i opravdanja. $\ll^{5}$

Kršćanstvo »s ljudskim licem« je dakle kršćanstvo »novoga čovjeka«, onoga koji nije zarobljen ljudskim natruhama i izmišljotinama »staroga čovjeka«, svijetom i njegovim »zakonima«, napose onima koje je tijekom stoljeća nametnuo kršćanima klerički personal, nego je pokristovljen Kristovom ljubavi da bi živio u »slobodi djece Božje«. »Ljudsko lice« kršćanstva je na kraju i Kristovo božansko-ljudsko lice. Izvan toga lica kršćanstva nema.

Kao što je potrebno poštivati osnovne, bitne religijske ideje i institucije kršćanstva, pa tako i jednu, svetu, apostolsku i univerzalnu Crkvu, kao i sve autentične kršćanske vjerske zajednice, ali i one drugih plemenitih religija, isto je tako prijeko potrebno konačno napustiti mnoge religijske ideologije i doktrine, konstrukcije, strukture, legalizme i juridizme kao njihovu bolesnu i otuđujuću natruhu koja ih izjeda i deformira iznutra. I to zato da bi se dalo prvo i bitno mjesto Kristu i autentičnom življenju Evanđelja te napustilo sve one zlokobne pojave, koje su se pod utjecajem svijeta i svjetovnog te njihova (ne)duha uvelike raširile već u prošlosti, a neke su ostale žive i u sadašnjosti. Među njima je i ona, jedna od najgorih, koju Željko Mardešić zove "političkim katolicizmom«. Ova njegova "projekcija«, zapravo apel za napuštanjem protuevanđeoskog i izgradnju istinski kristovskog, ima doista proročki karakter koji se može najbolje nazrijeti iz širega konteksta u koji je stavlja ocrtavajući obrise budućnosti Crkve i kršćanstva, vjerne njihovoj izvornosti.

\section{Kakva budućnost?}

U čemu je ta izvornost? Nije riječ samo o vjernosti povijesnim izvorima i čistim počecima, autentičnoj tradiciji ili možda onom najboljem iz prošlosti, nego još više o onome što je iznad i izvan svakog vremena, zov vječnosti, nadvremenska vrijednost. A takav je zov par excellence proročki. Ovdje ćemo se ograničiti na samo dva njegova aspekta koji se tiču budućnosti.

Prvi se tiče Mardešićeve proročke vizije Crkve za predstojeća vremena, poticaja da Crkva, kao sveukupan Božji narod, prema svojem prvotnom iskonskom značenju i pozivu, okupljena u bratsku zajednicu s Kristom kao svojom glavom i mistično, nevidljivo obuhvaćajući i one koji Krista možda neće nikad na ovome svijetu upoznati niti za njega čuti, dakle s onu stranu svih pojavnosti, vremena, jezika i kultura, zapravo svih ljudskih različitosti postane svojim životom, prisutnošću i djelovanjem univerzalna Crkva. U svojoj bîti ona je dakako od samoga svojeg osnutka to i bila, što se, međutim, u konkretnom povijesnom

${ }^{5}$ Isto, 99-100. 
slijedu i zbivanju nije uvijek ostvarivalo i vidjelo, katkad nimalo, a katkad tek nepotpuno.

Kako ističe Mardešić, u vremenima koja dolaze prijeko je potrebno da Crkva, kako ne bi izdala svoj izvorni, pravi smisao,

"postane što potpunijom: Crkvom siromaha i zapostavljenih, Crkvom dobrote i milosrdne ljudskosti, Crkvom nade i radosti, Crkvom mirotvorstva, pomirenja i praštanja i Crkvom iskrena dijaloga sa suvremenim svijetom «. ${ }^{6}$

A ne da se pretvara (gotovo) u vlastitu suprotnost, što je dovodilo kroz povijest katkada i do katastrofalnih devijacija, deformacija i tragedija. U ovoj, od pape Franje proglašenoj »Godini milosrđa«, vrijedno je prisjetiti se da je već prije desetak godina Željko Mardešić pozivao na to da Crkva bude Crkvom »milosrdne ljudskosti«. U srži Kristove poruke uostalom i stoji poruka ljudskosti i čovječnosti koja je u biti poruka ljubavi. Kako bi Crkva mogla biti Kristovom, a da uvijek i svugdje ne bude duhom i djelima svojih članova na tome bitnom tragu? Jer, udaljujući se od toga traga i puta ljubavi, postala bi izdajničkom, udaljila bi se od samoga Krista. Stoga je Mardešić opravdano proročki pisao:

»Ako se kršćani ne ljube nisu učenici, nisu Crkva, iako mogu misliti da su pravovjerni i krjeposni. Od te ljubavi Crkva živi i od te ne-ljubavi Crkva umire. Postaje, u drugom slučaju, gangrenozno tkivo smrti i raspadanja, čudovište neslobode i grob istine. «?

Ovim doista teškim riječima Mardešić je hrabro progovorio o nepobitnoj povijesnoj istini i duhovnoj činjenici s kojima bi se svi kršćani, a napose klerički personal, morali iskreno suočiti. Nasuprot farizejskim lažima, licemjerju, himbi i prijetvornosti punima kompromisa i niskih izdaja, pohlepi za materijalnim interesima, povlasticama, častima i položajima, samodostatnosti i umišljenosti te odbijanju svake samokritike, vlastitu mnogim pripadnicima kleričkog personala Crkve, ali i onome drugih religija - valja snažno istaći visoke i svijetle primjere njezinih članova, članova klera i onih koji to nisu, koji su kroz njezinu dugu dvotisućljetnu povijest bili iskreni služitelji Crkve i čovjeka, znajući da on nije »radi subote«, tražeći istinu i pravdu te samozatajno radeći na mnogim dobrima za čovječanstvo i čovjeka na tragu njihova Učitelja. To se ne smije zaboraviti niti smije zanijekati nasuprot vulgarnim izrugivačima i plitkim osporavateljima kršćanstva, slijepima za visinu njegove poruke i za tolika vrijedna i zadivljujuća djela tolikih kršćana. Kratkovidno nijekanje najplemenitijih kršćanskih vrijednosti uime prizemnih predrasuda, često zbog katastrofalnog nepoznavanja kršćanstva, kakvo se u zadnje vrijeme sve više zapaža i u nekim krugovima u Hrvatskoj, svjedoči o žalosnoj pojavi koja govori, barem u konačnici, najviše o stanju (ne)duha onih koji su njezini nositelji.

${ }^{6}$ Ž. MARDEŠIĆ, Crkva i suvremeni svijet: današnje perspektive, Bogoslovska smotra, 75 (2005) 3, 905-936, 935.

7 Ž. MARDEŠIĆ, Rascjep u svetome, Zagreb, Kršćanska sadašnjost, 2007, 170. 
Što se pak tiče samoga kršćanstva, za koje bismo voljeli da ga je Mardešić u svojim tekstovima jasnije i izričitije razlikovao od kršćanskog svijeta, to jest ljudi, kršćana, ali i pseudokršćana koji često nisu bili na visini istinskog kršćanstva uz koje su izvanjski pristajali i deklarirano pripadništvo kojih nije uvijek značilo i dubinsko duhovno pristajanje te njemu dosljedno življenje, postupanje, djelovanje i ponašanje Mardešić je imao jasnu viziju njegove jedino plodne i istinske budućnosti. On je vidio »kršćansku budućnost«: »Izvan svih kolektivističkih i ideologijskih vizija kršćanstva, koje su u prošlosti tom istom kršćanstvu nanijele nenadoknadive sramote i poraze«; u zauzimanju »za jedno doista posve personalističko kršćanstvo, skupljeno u malim zajednicama, po mjeri ljudskosti«; u prestanku traženja ikakva korisnog povezivanja s politikom; u povjerenju »u slobodu i slobodnog čovjeka... demokraciju i građansko društvo, unatoč njihovim nedostacima«; konačno, u nastojanju mijenjanja najprije sebe, a ne svijeta, jer je mijenjanje svijeta nabolje moguće jedino nakon pokušaja promjene sebe. ${ }^{8}$

Sigurno, proročkih bi se elemenata u Mardešićevu djelu moglo još naći, a njihovi razni aspekti raščlaniti i artikulirati. No i već ovi ovdje spomenuti dovoljni su da se shvati veličinu njegove "proročke vizije« koja obuhvaća i sačinjava monumentalan, gotovo sveobuhvatan projekt za budućnost čiji su dometi bitni, temeljni i krajnje važni.

\footnotetext{
${ }^{8}$ Usp. Ž. MARDEŠIĆ, Svjedočanstva o mirotvorstvu, Zagreb, Kršćanska sadašnjost, 2002, 53-54.
} 


\section{Ivan Supičić"* \\ On the prophetic spirit of Željko Mardešić \\ Summary}

The work of Željko Mardešić is strongly marked by scientificity and spirituality. But it also has an undeniable prophetic character. And this not only in a sense of a possible "predictions" of future events, but in the most part also in deeper foresights of reality which are not discovered and expressed by others. Mardešić reaches the essential problems of the contemporary world in its spiritual state of mind. Today's man is exposed in it to numerous splits, self-deceptions, illusions and false appearances; he is able to lie to himself and to others, to be true or alienated, just to appear or to really be. This can grow even to collective dimensions. Some Mardešićs projections about Church and Christianism witness of interconnection of their spiritual and scientific aspects. According to Mardešić, the Church should be a Church of poor and neglected, of deep humanness, of hope and joy, of reconciliation and forgiving and of sincere dialogue with the contemporary world. Mardešić is also deeply committed to an entirely personalistic Christianism, outside of any collectivistic and ideological visions, to cessation of its linking with politics, which led in the past to worst deformations, and to trust in freedom and in free man. The world can change only if we change ourselves first. The Christianism of future must find again its original "human face“, which is nothing else than the divine-humain face of Jesus Christ.

Key words: Željko Mardešić, prophetic spirit, distortions of consciousness, Christianism with a human face, the future of Church and Christianism.

(na engl. prev. Ivan Supičić)

\footnotetext{
* Academician Ivan Supičić, Address: Croatian Academy of Sciences and Arts, Trg Nikole Šubića Zrinskog 11, HR-10000 Zagreb, Croatia; E-mail: supicic.ivan@gmail.com.
} 